\title{
Improving the Transparency of the Life History Method Data Analysis Process in Qualitative Biographical Research
}

\author{
Mare Sadam $^{1}$, Larissa Jógi² ${ }^{2}$ Ivor Frederick Goodson ${ }^{3}$
}

\section{School of Educational Sciences, Tallinn University, 25 Narva rd., EE-10120, Tallinn, Estonia, mare.sadam@tlu.ee School of Educational Sciences, Tallinn University, 25 Narva rd., EE-10120, Tallinn, Estonia, larissa.jogi@tlu.ee Education Research Centre, University of Brighton, Checkland Building, Falmer, BN1 9PH Brighton, United Kingdom, I.F.Goodson@brighton.ac.uk}

Abstract. The transparency of the data analysis process is one of the main criteria for the empirical reliability of qualitative biographical research based on the life history method (LHM). The aim of the paper is to examine the transparency of the data analysis process used in published scientific papers based on LHM. The results show that the data analysis process is not fully transparent. Two kinds of analysis process were mainly used in research with LHM: categorical content analysis and portrayal.

Keywords: life history method; qualitative biographical research, empirical data analysis process; transparency; portrayal method.

\section{Introduction}

The life history method (LHM) has been used in qualitative biographical research for more than a century and has become common in the field of educational sociology in recent decades. It has been found to be an effective way to view an individual's life on a societal level and to investigate human experience in its broader political, socio-economic and historical context; it has been perceived as a means of giving a voice to those who cannot influence public policy but must merely surrender to it (Goodson, 2014; Erben, 1998).

LHM is a qualitative research method that encompasses both the broader social and historical context and the individual lives within it. In light of the critiques of LHM we 
focus on the transparency of the data analysis process in order to further develop the method and examine the empirical data analysis process used in current research*.

Our aims in this paper were first to develop an overview of how empirical data had been analysed by other researchers using LHM, and second to examine and discuss the transparency of the process. We use LHM to investigate teachers' values in relation to societal values in order to answer the question of how societal values affect teachers' lives. The sample is comprised of teachers from Estonia, which has experienced a rapid change from an ideology- to a market-based society, providing us with a unique opportunity to analyse the relationship.

Among other things, LHM enables us to examine the 'hidden history' of those whose story differs from recorded history. Producing informal narrative histories allow us to characterise human actions - a feature of communal memory (Connerton, 1989). LHM could be used in contemporary times as a means of giving a voice to those who have no opportunity to shape public policy but must merely accept and live with it (Goodson, 2014). For instance, there is ample empirical quantitative evidence that children from lower-working-class homes do not perform as well at school as children from uppermiddle-class homes. Complementary results of biographical research provide what could not be obtained from quantitative research - a deeper understanding of the historical context of individual experience and its empirically observable features. That is a good example of the kind of research in which a biography provides additional information and greater qualitative comprehension to quantitative research results (Erben, 1998). An analysis of these examples confirmed our understanding that the method is perceived as especially suitable for analysing personal life in relation to the societal context. Therefore, we selected LHM for a research project currently in progress ${ }^{1}$, as the method makes it possible to simultaneously consider both the personal and societal spheres of life (Goodson, 2013, Goodson and Sikes, 2001). In the current paper our primary aim is to improve the reliability of LHM for future research, and second, to examine the process of empirical data analysis underlying the research in progress ${ }^{*}$.

\section{The focus of the current paper}

In the current paper the problem placing addresses two developments: first, there is no generally accepted data analysis process in LHM, and second, the criteria for qualitative research reports that require a clear description of the data analysis process.

Research in progress concerning teachers' values in relation to societal values is supported by a Dora Plus grant, Sub-activities 1.1 and $1.2 \mathrm{http}: / /$ haridus.archimedes.ee/en/dora-phd-mobility 
The latest publications about LHM confirm that although the term 'methodology' is generally understood to mean a cluster of well-established practices governed by uncontested conventions, the literature shows that this understanding does not apply to narrative and life history research projects. There is no consensus that compels a commitment to this type of work (Kalekin-Fishman, 2017). Furthermore, creativity and the uniqueness of the process lie at the heart of qualitative research based on LHM. Because each instance of qualitative research is perceived as a unique process requiring the researcher to craft his or her own method, flexibility, versatility, and creativity have been emphasised, and methodological ambiguity tolerated as an inescapable, even desirable, component of the process. A systematic delineation of the full research course in advance, including the method of analysis, is deemed not only unnecessary, but impossible (Tuval, 2017).

However, such unique and creative research processes are expected to be explicit according to current criteria for qualitative empirical research reports. For example, the Standards for Reporting on Empirical Social Science Research in AREA Publications states that reporting should specify the logic of inquiry as well as the activities that led from the initial development of interest, the topic, problem, or research question, through the definition, collection, and analysis of the data or empirical evidence, to the articulated outcomes of the study. And of most relevance to our subject, the following criteria are provided for communicating the transparency of the process of analysis:

1) The process of developing the descriptions, claims, and interpretations should be clearly described and illustrated. The description should make it possible to follow the course of decisions about the pattern descriptions, claims, and interpretations from the beginning to the end of the analysis process. 2) The evidence that serves as a warrant for each claim should be presented. The sources of evidence and the strength and variety of evidence supporting each claim should be described. Qualifications and conditions should be specified; significant counter-examples should be reported. Claims should be illustrated with concrete examples. 3) Practices used to develop and enhance the warrant for the claims should be described including the search for disconfirming evidence and alternative interpretations of the same evidence. 4) Interpretive commentary should provide a deeper understanding of the claims - how and why the patterns described may have occurred; how they relate to one another, how they relate to (support or challenge) theory and findings from previous research, and what alternative claims or counter-claims were considered (Standards for Reporting on Empirical Social Science Research in AREA Publications, AREA, 2006).

Therefore, in light of the critiques of LHM, our focus in the current paper is on the transparency of the data analysis process, in the interests of the further development of the method. We decided to make published scientific papers in which LHM was used the object of our analysis; Ivor Goodson's LHM served as a resource (Goodson, 2013; Goodson and Sikes, 2001); categorical form reading (Lieblich, Tuval-Mashiach and Zilber, 1998) was employed as our method of analysis; and we followed the model describing the 
transparency of qualitative research (Tuval-Mashiach, 2017) to formulate our criteria. Our aims were first to develop an overview of how empirical data had been analysed by other researchers using LHM, and second to examine and discuss the transparency of the process. The latter unexpectedly became more complicated because of a lack of clarity in describing the process of analysis.

\section{The life history method and the transparency of the data analysis process}

The purpose of LHM is to seek the human experience in different contexts, in order to enable analysis and demonstrate the links between the societal and the personal, and to breathe life into historically recorded events by considering the human experience. It demands from the researcher the ability to work with 'empathetic' data, to listen and analyse beyond what is actually being said (Goodson and Sikes, 2001).

LHM involves detailed empirical findings, imaginative reconstruction, a sense of history, the discernment of moral frameworks, and interpretation of everyday existence. A significant philosophy of biography was advanced by Paul Ricoeur, who asserted that individual volition and societal influence are indissolubly joined in the narrative characteristics of human identity. 'Time is the structure of existence that reaches language in narrativity and narrativity is the language structure that has time as its ultimate referent' (as quoted in Erben, 1998).

Reliability has been a long-standing issue for developers and users of the method, and research has been undertaken to find the solution to increasing the reliability of the analysis process. LHM has been seen as a subjective method that makes generalisation difficult. Life history studies have been perceived to be merely 'telling tales', and reservations about the methodology have led to its generally inferior status in the scientific literature, especially in the context of modernism (Goodson, 2001; Goodson and Sikes, 2001). However, it should be noted that the aim of life history work is not to establish objectivity or facticity, but to represent facticity in its many forms. Reliability in LHM framework refers to the representation of subjectivity and not to the establishment of facticity or objective truth.

On the one hand, therefore, the question of subjectivity should not change; on the other hand, it is necessary to meet the current standards for scientific publications (Standards for Reporting on Empirical Social Science Research in AREA Publications, 2006). Reliable research reports facilitate dialogue and mutual understanding between international and interdisciplinary audiences (Skukauskaite and Green, 2011). The solution to increasing the reliability of LHM may be in improving the transparency of analysis process. This would not make the results more objective, but would increase the credibility of the 
research by making its logic and process of analysis - the connection between the data and the results - explicit.

\section{Sample papers}

Our sample was selected according to the principle of purposive sampling, using the scientific literature search system "EBSCO Discovery Service", a multi-source research tool, which enabled us to query more than 50 licenced databases.

The search for the papers was made in 'All Text' mode, because not all authors provide keywords or mention the research method in the keywords or titles. The initial search for the phrase 'life history method used' yielded 1162 records. We narrowed the search to peer-reviewed papers in academic journals and continued with the phrases 'Goodson "life history method", which produced 307 records. That search identified not only papers in which LHM had been used as a research method but also papers about LHM and other content irrelevant to our research. A subsequent search with phrases 'Goodson 'Life History Method used" found 36 records; however, because too many papers in which LHM had been used were not included, we continued with the results of the previous search, omitting articles written by Goodson, which yielded 281 results. Of those, we continued with the 165 that were from the field of educational studies. After that we omitted articles published before the year 2000 in order to focus on the development of the presentation of the data analysis in recent decades, which produced 125 papers that had been published in 88 different academic journals. We continued to winnow our sample manually, verifying that all the papers were written by different authors to ensure that the presentation of the analysis process would not be similar merely because of the style of one author or journal. Some publications were omitted because the full text was not available, Goodson was mentioned not as the source of the methods but in some other part of the paper, or because of another factor that was not revealed in the automated search. The size of the sample was finalised according to the principle of saturation (Glaser and Strauss, 1967). In order to answer our research question, we examined the data analysis in nine studies in which LHM was used. In some papers (for instance, Duckworth and Ade-Ojo 2016; Tarpey, 2016) LHM was combined with other methods. The selected papers were published between 2001 and 2018. They are represented in the current paper by the letters a, b, c, d, e, f, g, h, i (see Table 1). 
Table 1

The papers that comprise the sample

\begin{tabular}{|c|c|c|c|c|c|c|}
\hline & Journal & Author (s) & $\begin{array}{c}\text { Year } \\
\text { published }\end{array}$ & $\begin{array}{c}\text { Research } \\
\text { method }\end{array}$ & $\begin{array}{c}\text { Life } \\
\text { history } \\
\text { in key- } \\
\text { words }\end{array}$ & $\begin{array}{c}\text { Referencing } \\
\text { Goodson } \\
\text { (among others) } \\
\text { in the metho- } \\
\text { dology }\end{array}$ \\
\hline (a) & $\begin{array}{l}\text { Professional Devel- } \\
\text { opment in Education }\end{array}$ & Amott, P. & 2018 & LHM & $\begin{array}{l}\text { life } \\
\text { history }\end{array}$ & + \\
\hline (b) & $\begin{array}{l}\text { Scandinavian Jour- } \\
\text { nal of Educational } \\
\text { Research }\end{array}$ & $\begin{array}{l}\text { Biott, C., } \\
\text { Moos, L., and } \\
\text { Møller,J. }\end{array}$ & 2001 & LHM & $\begin{array}{l}\text { life } \\
\text { history }\end{array}$ & + \\
\hline (c) & $\begin{array}{l}\text { Teaching and Teacher } \\
\text { Education }\end{array}$ & $\begin{array}{l}\text { Choi, P. L., and } \\
\text { Tang, S. F. }\end{array}$ & 2009 & LHM & $\begin{array}{l}\text { life } \\
\text { history } \\
\text { method }\end{array}$ & + \\
\hline (d) & $\begin{array}{l}\text { Journal of Transform- } \\
\text { ative Education }\end{array}$ & $\begin{array}{l}\text { Duckworth, V., } \\
\text { and } \\
\text { Ade-Ojo, G. }\end{array}$ & 2016 & $\begin{array}{l}\text { partic- } \\
\text { ipatory } \\
\text { action } \\
\text { research } \\
\text { (PAR); } \\
\text { LHM }\end{array}$ & $\begin{array}{l}\text { Not } \\
\text { listed in } \\
\text { the key- } \\
\text { words }\end{array}$ & + \\
\hline (e) & Support for Learning & Glazzard, J. & 2014 & LHM & $\begin{array}{l}\text { life } \\
\text { history }\end{array}$ & + \\
\hline (f) & $\begin{array}{l}\text { International Journal } \\
\text { of Qualitative Studies } \\
\text { in Education }\end{array}$ & Page, J. & 2014 & LHM & $\begin{array}{l}\text { life } \\
\text { historical }\end{array}$ & + \\
\hline (g) & $\begin{array}{l}\text { European Early } \\
\text { Childhood } \\
\text { Education } \\
\text { Research Journal }\end{array}$ & $\begin{array}{l}\text { Smedley, S., \& } \\
\text { Hoskins, K. }\end{array}$ & 2017 & LHM & $\begin{array}{l}\text { life } \\
\text { history }\end{array}$ & + \\
\hline (h) & $\begin{array}{l}\text { Changing English: } \\
\text { Studies in Culture } \\
\text { and Education }\end{array}$ & Tarpey, P. & 2016 & $\begin{array}{l}\text { LHM } \\
\text { com- } \\
\text { bined } \\
\text { with the } \\
\text { collective } \\
\text { memory } \\
\text { method }\end{array}$ & $\begin{array}{l}\text { life } \\
\text { history }\end{array}$ & + \\
\hline (i) & $\begin{array}{l}\text { Studies in Art } \\
\text { Education }\end{array}$ & $\begin{array}{l}\text { Trafi-Prats, L. T., } \\
\text { and } \\
\text { Woywod, C. W. }\end{array}$ & 2013 & LHM & $\begin{array}{l}\text { No key- } \\
\text { words } \\
\text { listed }\end{array}$ & + \\
\hline
\end{tabular}




\section{Method}

We used categorical form reading, a type of categorical content study that can also be used to analyse life stories (Lieblich, Tuval-Mashiach and Zilber, 1998), to analyse how the data analysis process was conducted and presented in the papers. We scrutinised and identified the process, even if it was not clearly presented. In order to determine whether the method of analysis was explicitly presented, we used the transparency model developed by RivkaTuval-Mashiach. According to the model, a researcher should answer three central questions: what was done, how it was done, and why it was done. The congruent conception of transparency holds the researcher responsible for clearly explaining the research process so that the reader can follow the steps taken in conducting the research and analysing the data (Tuval-Mashiach, 2017). The transparency model is applicable to all aspects of the research process; however, our focus is on the process of analysing the empirical data. We used the three questions - what was done, how it was done, and why it was done - as a framework and added some aspects specific to our subject. This resulted in the following model for analysing transparency:

(1) What was done. Was the method of analysis used by the researcher(s) specified? For example, was there a subchapter describing the analysis process? Since the analysis process for LHM is not prescribed, it is not enough to simply refer to LHM to present the analysis process.

(2) How it was done. Was the analysis process explained? How were the results presented? We tried to identify the method of analysis even when it was not named and explained or was only named. The tendency in the methodology literature to refer to various research methods or models of analysis as brand names without offering further details has also become prevalent among researchers writing papers about qualitative research (Tuval-Mashiach, 2017).

(3) Why it was done. Why was the method of analysis selected?

\section{Results}

The results pertaining to the analysed papers are presented in Table 1, Table 2 and the appendix. They indicate that in six papers $(b, d, e, g, h, i)$ the data analysis process was not sufficiently transparent. Readers who are familiar with LHM would probably be able to identify the process and draw their own conclusions about the methods of analysis that were used; for example, by the way the results are presented. However, for readers with a different research background, the process might not be clear.

We identified the method of analysis even when it was not described (b, d, g, h, i), and classified the papers on the basis of coding: 1) methods in which the data were decontextualised and recontextualised, or 2) methods in which the data were not decontextualised 
during analysis. During decontextualization the analyst separates data from the original context of individual cases and assigns codes to units of meaning in the texts. In recontextualization he or she examines the codes for patterns and then reintegrates, organizes, and reduces the data around central themes and relationships drawn across all the cases and narratives (Starks and Trinidad, 2007). The first type of method we deemed to be categorical content analysis. Grounded theory analysis was also classified as Type 1 because it is based on inductive three-level coding and the subsequent derivation of categories, identification of connections and their hierarchy (Charmaz, 2006 ). The second type, which maintains a unified life story throughout the research and approaches the analysis more holistically without coding and categorising, we considered to be portrayal. Portrayal, the term used by Goodson for analysing data in LHM (Goodson, 2013), is discussed below.

It was found that two main forms of analysis were used - categorical content analysis and portrayal. Therefore, nine scientific papers constituted an adequate sample to meet the criterion of saturation of data (Glaser and Strauss, 1967). There was no need to increase the number, as additional papers would also have fitted into the two categories.

We identified the type of data analysis method used in the papers (Figure 1).

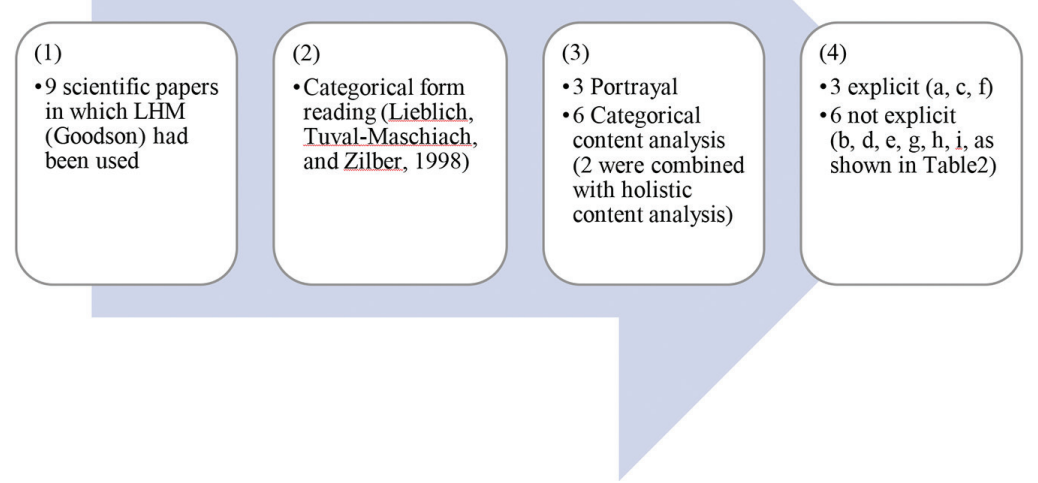

Figure 1. Overview of the analysis undertaken in the paper

In six of the papers (b, d, e, g, h, i) the data analysis process was not explicit. Only in four cases ( $a, b, c, f)$ wasthe analysis process distinctly named, indicating that particular attention was paid to it. In these cases it was found that the researchers were more explicit about the whole analysis process, although the third question of our transparency model - Why it was done - was not answered. The researchers explained why they had used LHM but not why they had chosen their method of analysis over other options. The results pertaining to the data analysis processes used in research based on LHM were as follows: 
- From the standpoint of the explicitness of the process of analysing empirical data, one paper in our sample, (f), stands out from the others. The methodology is given more attention - the author describes every level of analysis and supports them with illustrative tables or schemes. In (c), the analysis is described in text form, and the process becomes explicit in the context of the whole paper. Many aspects of (b) were explicit, and the analysis process was distinctly identified; however, the stages of the process were not clearly presented, e.g., what was done after the narratives were collected. Readers who are familiar with LHM would deduce that the process had been based on content analysis, but this would not be clear to readers with a different research background (see (b) in the appendix).

- In cases in which portrayal was used, and a complete life history account included in the paper, the result was transparent, and readers would be able to draw their own conclusions about the information that is 'beyond words'. Nevertheless, the data analysis process might not be explicit. The portrayal process was not explained in the papers included in our sample, so the link between the data and the results might not be clear to the reader. Including the complete account did not make reading the paper onerous, so this could be a viable option for presenting the data if the number of participants is not too high, since it adds to the length of the text. There were 1-23 participants in the research in our sample, and a full account was presented in two papers: (d), Table 2-2 participants, and (e), Table 2-1 participant.

- Neither the analysis process nor an account was presented in (i), Table 2, in which the research was based on portrayal. In this case, the result was a video (video-portrayal), which obviously could not be added to the paper.

- One issue that was not explicit in most of the papers was the coding, which varied. In the case of content analysis, it was difficult to determine how many levels of coding were used - whether it was open coding, as the initial phase of coding is called in qualitative content analysis (Elo and Kyngäs, 2008), or whether the codes were further processed in order to find causal connections and reveal new categories of themes. In research based on portrayal the term 'coding' was not used; although identifying emerging themes refers to open coding, the process was not explicit.

- An additional comment can be made that in introducing the sample, describing the analysis process or presenting the results, words were used rather than schemes or tables. For example, the sample and categories of themes were presented in table form in only three of the papers $(\mathrm{a}, \mathrm{c}, \mathrm{f})$. The stages of data analysis were schematically presented in only one of them (f). Presenting the results in the form of text seems to be common for researchers who make use of stories; however, for readers with a different research background and for those who are seeking a brief overview, summarising schemes and tables would have been helpful. On the other hand, presenting the data in text form can be done by including a complete life history account in the paper, as in (d) and (e) in Table 2, which has additional advantages. 
- It was also found that papers that made use of some form of categorical content analysis were more explicit about the data analysis process, although those based on portrayal might be the most explicit because the complete account was included in the text. This prompted us to provide an explanation of the stages of portrayal below.

Table 2

Results of the analysis

\begin{tabular}{|c|c|c|c|c|c|c|}
\hline & & What? & What?; How? & How? & Why? & Transparency \\
\hline Paper & $\begin{array}{l}\text { Sample } \\
\text { size }\end{array}$ & $\begin{array}{l}\text { Analysis } \\
\text { process } \\
\text { identified }\end{array}$ & $\begin{array}{l}\text { Method of data } \\
\text { analysis }\end{array}$ & $\begin{array}{l}\text { Presentation of } \\
\text { results }\end{array}$ & $\begin{array}{l}\text { Why the } \\
\text { method was } \\
\text { selected }\end{array}$ & $\begin{array}{l}\text { Analysis pro- } \\
\text { cess explicit/ } \\
\text { not explicit }\end{array}$ \\
\hline (a) & 6 & $\begin{array}{l}\text { Inductive } \\
\text { analysis based } \\
\text { on grounded } \\
\text { theory }\end{array}$ & $\begin{array}{l}\text { Categorical } \\
\text { content } \\
\text { analysis }\end{array}$ & Thematic order & - & Explicit \\
\hline (b) & 12 & $\begin{array}{l}\text { Dialogical } \\
\text { analysis }\end{array}$ & $\begin{array}{l}\text { Categorical } \\
\text { content analysis } \\
\text { combined with } \\
\text { holistic content } \\
\text { and form analysis }\end{array}$ & & + & $\begin{array}{l}\text { Explicit } \\
\text { except for } \\
\text { coding levels }\end{array}$ \\
\hline (c) & 23 & $\begin{array}{l}\text { Constant } \\
\text { comparative } \\
\text { coding }\end{array}$ & $\begin{array}{l}\text { Categorical con- } \\
\text { tent analysis }\end{array}$ & $\begin{array}{l}\text { Results presented } \\
\text { in the order of } \\
\text { emerging factors, } \\
\text { tables provided }\end{array}$ & + & Explicit \\
\hline (d) & 2 & - & Portrayal & $\begin{array}{l}\text { Complete } \\
\text { accounts }\end{array}$ & - & $\begin{array}{l}\text { Not explicit. } \\
\text { Portrayal } \\
\text { used but not } \\
\text { explained }\end{array}$ \\
\hline (e) & 1 & - & Portrayal & $\begin{array}{l}\text { Complete ac- } \\
\text { count written by } \\
\text { participant }\end{array}$ & - & Not explicit \\
\hline (f) & 6 & $\begin{array}{l}\text { Thematic } \\
\text { analysis }\end{array}$ & $\begin{array}{l}\text { Categorical } \\
\text { content analysis }\end{array}$ & $\begin{array}{l}\text { Thematical } \\
\text { stories of the } \\
\text { participants }\end{array}$ & + & Explicit \\
\hline (g) & 9 & - & $\begin{array}{l}\text { Categorical con- } \\
\text { tent analysis }\end{array}$ & Thematical order & - & Not explicit \\
\hline (h) & 6 & - & $\begin{array}{l}\text { Categorical }+ \\
\text { holistic content } \\
\text { analysis }\end{array}$ & $\begin{array}{l}\text { Discussion in } \\
\text { thematical order }\end{array}$ & - & Not explicit \\
\hline (i) & 3 & - & $\begin{array}{l}\text { Portrayal } \\
\text { (video) }\end{array}$ & $\begin{array}{l}\text { Discussion in } \\
\text { thematical order }\end{array}$ & - & Not explicit \\
\hline
\end{tabular}


Additional examples of transparency or a lack thereof are presented in the appendix. Abbreviated results of the analysis are presented in Table 2. We identified aspects of the papers according to the transparency model: Was it explained (1) What was done, (2) How it was done, and (3) Why it was done. Since the data analysis process tended not to be explicit, we also examined the way in which the results were presented in order to divine what had been done during the data analysis process, and included those findings in Table 2.

\section{Proposed approaches to increasing the transparency of the data analysis process}

The results indicate that first, researchers tend not to be explicit about the analysis process. This provides a starting point for our discussion: how might researchers using LHM present the empirical data analysis process more clearly in order to increase the credibility of the research.

Second, our examination of methods of analysis found that the process generally involved either portrayal or categorical content analysis. The process of categorical content analysis was more explicit when researchers explained the coding process: was it inductive or deductive; how many stages of coding were conducted. The tendency of researchers portraying life stories to present all of the content in the text provides another means of increasing the explicitness of empirical data analysis, whereas tables and schemes are more comprehensible to readers with a different research background. Nevertheless, the results could still be presented in words, e.g., in the form of life histories.

Although researchers making use of portrayal in LHM have been criticised for 'only telling tales' (Goodson, 2001), the inclusion of tales in academic texts is reasonable when presenting empathetic data that is 'beyond words', i.e., tacit knowledge, which is especially common in training teachers (Elliot, 1998).

Presenting the complete story in the academic text is usually done when portrayal is used as the analysis process; however, it can be a complementary option in the case of categorical content analysis and may reveal additional aspects of the findings; much can be done to refine and deepen the interpretation of the themes in the story. Not everything in a story can be taken literally or classified thematically. For instance, narrators may use irony. Considering the types of discourse in each sequence of an interview can be very informative (Horsdal, 2017). 


\section{Explanation of the portrayal method of analysis}

Before introducing the way in which the analysis process is conducted by Goodson in LHM (Goodson and Sikes, 2001) we would like to emphasise that researchers should be trusted to make their own decisions about the best way to analyse the data; therefore, a method of analysis cannot be prescribed. Moreover, our search for a suitable data analysis process is not meant to be regarded as a prescription, but rather as an option for consideration.

One form of suggested analysis is portrayal (Goodson, 2013). There are four stages of empirical data analysis in the process of portrayal: (1) Listening during the interview; (2) Listening during transcription; (3) Identifying emerging themes; (4) Placing the interpreted narrative in its historical context (Figure 2).

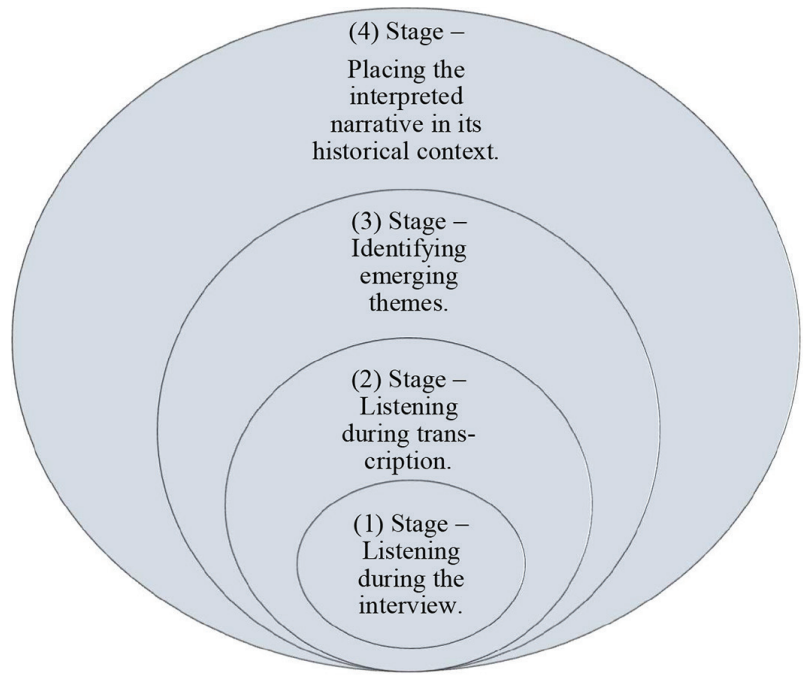

Figure 2. Stages of empirical data analysis in the process of portrayal

(1) The first stage of analysis: Listening during the interview. The aim is to capture the story as it is, rather than the way a researcher expects it to be. In LHM listening is considered to be the initial stage of processing the data. Furthermore, a researcher can make an assessment even before the interview, at the time of the first contact with the participant. An important aspect of obtaining an accurate story is limiting the questions to those that help to keep it flowing. The best interviews are those in which the researcher elicits long periods of narrative from the participant. Listening without a long list of questions facilitates: 1) fully giving voice to the interviewee; 2) discovering new knowledge that the researcher would not have been able to predict; and 3) basing the research on the principle of grounded theory - 
theory that is derived from the data, usually without a pre-formulated hypothesis (Goodson, 2014; Goodson, 2011; Connerton, 1998; Strauss and Corbin, 1998). More than one interview would normally be conducted, and the researcher would only be permitted to ask clarifying questions in the second or subsequent interviews (Kalekin-Fishman, 2017). A life story interview is an approach that is best suited to researchers who can ask pertinent questions in an impartial manner and who are able to listen attentively and beyond what is actually being said (Goodson and Sikes, 2001).

Although good researchers are expected not to ask too many questions and to listen quietly, they may rely on their experience to build trust and create a conversational interaction by sharing their own experience with an interviewee (Denzin, 2001).

(2) The second stage of analysis: Listening during transcription. The aim, first of all, is to listen closely, after the novelty of the interview situation has worn off, and second, to identify themes that may need clarification in a possible second interview. Because transcribing the interview is seen as one of the stages of analysis, and not merely as preparation, (Gibbs, 2007) it is preferable that the work be done by the researcher and not by an assistant. Even if someone else does the transcription, the researcher should listen to the recording. Such close listening is important because meaning is conveyed as much through the way in which something is said as through the actual words that are used (Goodson and Sikes, 2017).

(3) The third stage of analysis: Identifying emerging themes. The aim of this stage is to read through the transcribed text and identify the themes that emerge. The themes should be significant from a research perspective, e.g., those that recur in many interviews. From a qualitative research perspective, e.g., in content analysis, this stage would be called Open Coding (Elo and Kyngäs, 2008).

(4) The fourth stage of analysis: Placing the interpreted narrative in its historical context. The aim of this stage is to refine the previous general thematic analyses, and to contextualise the analysis in order to provide a basis for the conclusions. The distinction between life stories and life histories lies in the contextual data. Through the inclusion of the historical background, life stories can be seen as social constructs against the backdrop of changing patterns of time and space. As mentioned above, by eliciting a personal story we also mediate between the personal voice and the wider cultural imperatives. Contextualisation enables LHM to make this mediation explicit (Goodson, 2013; Goodson and Sikes, 2001).

Portrayal is one of many ways in which LHM data can be analysed, and, as mentioned above, specific techniques of analysis are not and should not be prescribed. The advantage of portrayal is that it best supports our assertion that in LHM and qualitative biographical research the person and the data should be connected throughout the process. 


\section{Discussion and Conclusions}

Each scientific project will have idiosyncratic needs and there are no easy instructions for using LHM. Qualitative biographical researchers can rely on the strength of subjectivity - the analysis is mainly performed by human beings using their senses, rather than by a computer or other automatic means in which the human being is only a technician. It is a method that requires the constant exercise of human judgement (Goodson, 2017, 2001). In order to interpret the data the researcher is required to use imagination - the ability to speculate, and to link and assemble ideas related to the research (Erben, 1998). Imagination can supply the connections between observations and their context that would be impossible to establish by reason alone (Hume, as quoted in Erben, 1998). Therefore, an analysis process cannot be prescribed. Our assertion that researchers should be trusted to make their own selection of a method of analysis is in accord with these statements. On the other hand, the extent of a researcher's knowledge of analytical procedures will have an influence on and be revealed in different forms and approaches to analysis. Therefore, it is important to be explicit about the analysis process in order to establish its credibility.

Our examination found that two kinds of analysis process were mainly used in research with LHM: categorical content analysis and portrayal. Regardless of which method was used, the data analysis process was not sufficiently explicit in the papers in our sample. The analysis process could be made more explicit by describing its stages consecutively, adding illustrative schemes and tables to each stage of analysis, and describing the coding principles. The presence of empathetic data 'beyond words' can be made explicit when presenting a complete life history account in its context, because such a story tells itself and is intrinsically informative. At the same time, some background can be provided for the story, such as causal exposition (Tarvel, 2002). Stories consist of remembered experiences and listeners can identify with stories of personal experience (Horsdal, 2012). If an interviewer can relate to the experience, so can the readers of scientific texts.

In conclusion, the way in which LHM can be used in the analysis process is revealed by the aims and premises of the researchers. Considering all the aspects and challenges of analysing a life story in its context, the ways in which LHM can be used is also dictated by the researcher's analytical skills. These include clearly describing the process in order to ensure reliability. Making the process explicit does not restrict a researcher's freedom to select a method of analysis. In most of the papers included in our study, the data analysis process was not explicit. Therefore, we believe that elucidation and improvement of the process is required, and that this paper lends support in that regard. 


\section{References}

Connerton, P. (1989). How Societies Remember. Cambridge: Cambridge University Press.

Charmaz, K. (2006). Constructing Grounded Theory. A Practical Guide Through Qualitative Analysis. London: Sage Publications.

Denzin, N. K. (2001). Interpretive Interactionism.Second Edition. Thousand Oaks: Sage Publications.

Elo, S. \& Kyngäs, H. (2008). The Qualitative Content Analysis Process. Journal of Advanced Nursing 62(1): 107-115. doi10.1111/j.1365-2648.2007.04569.x

Elliot, E. W. (1989). The Kind of Schools We Need: Personal Essays. Portsmouth: Heinemann.

Erben, M. (1998). Biography and Research Method. In Biography and Education: A Reader, edited by M. Erben,Social Research and Education Studies Series: 19. London: Falmer Press.

Gibbs, R. G. (2007). Analyzing Qualitative Data. London: Sage Publications.

Goodson, I. F. \& Sikes, P. (2017). Techniques for Doing Life History.In The Routledge International Handbook on Narrative and Life History, edited by I. F. Goodson, A. Antikainen, P. Sikes, and M. Andrews, 72-88. London: Routledge.

Goodson, I. F. (2014). Investigating the Life And Work of Teachers. EestiHariduseAjakiri [Estonian Journal of Education] 2(2), 28-47. doi:10.12697/eha.2014.2.2.02b

Goodson, I. F. (2013). Developing Narrative Theory: Life Histories and Personal Representation. New York: Routledge.

Goodson, I. F. (2011). Life Politics: Conversations about Culture and Education. Rotterdam: Sense Publishers.

Goodson, I. F. (1992). Studying Teachers' Lives: an Emergent Field of Inquiry. In Studying Teachers' Lives, edited by I. F. Goodson, 1-17. New York: Teachers College Press.

Goodson, I. F. \& Gill, S. R. (2011). Narrative Pedagogy: Life History and Learning. New York: Peter Lang.

Goodson, I. F. (2001). The Story of Life-History: Origins of the Life History Method in Sociology. Identity, 1 (2), 129-142.

Goodson, I. F. \& Sikes, P. (2001). Life History Research in Educational Settings: Learning from Lives. Buckingham; Philadelphia: Open University Press.

Horsdal, M. (2017). The Narrative Interview - Method, Theory and Ethics: Unfolding a Life. In The Routledge International Handbook on Narrative and Life History, edited by I. F. Goodson, A. Antikainen, P. Sikes, and M. Andrews, 260-269. London: Routledge.

Horsdal, M. (2012). Telling Lives: Exploring dimensions of narratives. London: Routledge.

Kalekin-Fishman, D. (2017). The Quest for Lived Truths: Modifying Methodology. In The Routledge International Handbook on Narrative and Life History, edited by I. F. Goodson, A. Antikainen, P. Sikes, and M. Andrews, 131-143. London: Routledge.

Lieblich, A., Tuval-Mashiach, R. \& Zilber, T. (1998). Narrative Research: Reading, Analysis, and Interpretation. Thousand Oaks: Sage Publications. 
Skukauskaite, A. \& Green. J. L. (2011). Review Essay: On Transparency, Epistemologies, and Positioning in Writing Introductory Qualitative Research Texts. Forum:Qualitative Social Research, Vol 13, Iss 1 (2011), (1).

Starks, H., \& Trinidad, S. B. (n.d.). Choose your method: A comparison of phenomenology, discourse analysis, and grounded theory. Qualitative Health Research, 17(10), 1372-1380. https://doi.org/10.1177/1049732307307031

Strauss, A. \& Corbin, J. (1998). Basics of Qualitative Research. Teaching and Procedures for Developing Grounded Theory. Thousand Oaks: Sage Publications.

Tarvel, E. (2002). Ajalugukuikaunismuinasjutt [History as a Beautiful Fairytale]. TunaAjalookultuuriAjakiri. [Tuna-Journal of the Culture of History], no. 2, 4-10.

\section{Sources used for the research}

Amott, P. (2018). Identification - a process of self-knowing realised within narrative practices for teacher educators during times of transition. Professional Development in Education, 44(4), 476.

Biott, C., Moos, L. \& Møller, J. (2001). Studying Headteachers' Professional Lives: Getting the Life History. Scandinavian Journal of Educational Research, 45(4), 395-410. doi: 10.1080/00313830120096798

Choi, P. L. \& Tang, S. F. (2009). Teacher Commitment Trends: Cases of Hong Kong Teachers from 1997 to 2007. Teaching and Teacher Education, 25(5), 767-777. doi:10.1016/j.tate.2009.01.005

Duckworth, V. \& Ade-Ojo, G. (2016). Journey Through Transformation: A Case Study of Two Literacy Learners. Journal of Transformative Educationm, 14(4), 285-304. doi:10.1177/1541344616644682

Glazzard, J. (2014). The Standards Agenda: Reflections of a Special Educational Needs Co-ordinator. Support for Learning, 29 (1), 39-53. doi: 10.1111/1467-9604.12044

Page, J. (2014). Childcare Choices and Voices: Using Interpreted Narratives and Thematic Meaning-Making to Analyse Mothers' Life Histories. International Journal of Qualitative Studies in Education, 27(7), 850-876. doi:10.1080/09518398.2013.805850

Smedley, S., \& Hoskins, K. (2017). Learning to be Froebelian: student teachers' life histories 1952-1965. European Early Childhood Education Research Journal, 25(1), 36.

Tarpey, P. (2016). 'Fire Burn and Cauldron Bubble': What are the Conjunctural Effects on English Teacher Professional Memories, Identities and Narratives? Changing English: Studies in Culture and Education, 23(1), 77-93. doi:10.1080/1358684X.2015.1133767

Trafí-Prats, L. \& Woywod, C. (2013). We Love Our Public Schools: Art Teachers' Life Histories in a Time of Loss, Accountability, and New Commonalities. Studies In Art Education, 55(1), 7-17. http://www-tandfonline-com.ezproxy.tlu.ee/doi/abs/10.1080/ 00393541.2013 .11518913 


\title{
Gyvenimo istorijos metodo duomenų analizès proceso skaidrinimas atliekant kokybinius biografinius tyrimus
}

\author{
Mare Sadam $^{1}$, Larissa Jógi ${ }^{2}$, IvorFrederick Goodson ${ }^{3}$ \\ 1 Edukologijos mokykla, Talino universitetas, Narvos kelias 25, EE-10120, Talinas, Estija, mare.sadam@tlu.ee \\ 2 Edukologijos mokykla, Talino universitetas, Narvos kelias 25, EE-10120, Talinas, Estija, larissa.jogi@tlu.ee \\ 3 Edukacinių tyrimų centras, Braitono universitetas, Checkland pastatas, Falmeris, BN1 9PH, Braitonas, Jungtinė \\ Karalystė, I.F.Goodson@brighton.ac.uk
}

\section{Santrauka}

Duomenų analizės proceso skaidrumas yra vienas pagrindinių kokybinių biografinių tyrimų, pagrịstų gyvenimo istorijos metodu (ang. lifehistorymethod (LHM)), empirinio patikimumo kriterijų. Pastaraisiais dešimtmečiais daugelis švietimo sociologijos srities mokslininkų gyvenimo istorijos metodą naudojo kokybiniuose biografiniuose tyrimuose žmogaus patirčiai nagrinėti.

Straipsnio tikslas - ištirti empirinių duomenų analizès procesų skaidrumą devyniuose publikuotuose moksliniuose darbuose, kuriuose buvo taikomas gyvenimo istorijos metodas, siekiant pagerinti šių procesų patikimumą. Išvados rodo, kad gyvenimo istorijos tyrimuose procesui analizuoti daugiausia buvo naudojami dviejų rūšių metodai: kategorinè turinio analizè ir aprašomasis metodas. Daugelyje nagrinètų dokumentų duomenų analizės procesas nèra visiškai skaidrus. Šiame straipsnyje pateikiami keli pasiūlymai, kaip aiškiau išdėstyti analizès procesą, siekiant padidinti gyvenimo istorijos metodo procedūrinị ir aiškinamąji patikimumą. Siekiant šio tikslo, pasirinktas aprašomasis metodas, kuris buvo naudojamas duomenų analizei ir gyvenimo istorijos metodo požymiams pateikti. Vis dèlto pažymėtina, kad gyvenimo istorijos darbo tikslas nèra nustatyti objektyvumą ar fakticiškumą, tačiau pavaizduoti fakticiškumą ịvairiomis jo formomis. Patikimumas gyvenimo istorijos metode susijęs su subjektyvumo pateikimu, o ne su fakticiškumu ar objektyvia tiesa.

Esminiai žodžiai: gyvenimo istorijos metodas, kokybinis biografinis metodas, empiriniųduomenų analizé, skaidrumas, aprašomasis metodas. 


\section{Appendix}

Table 3

Examples of the results

$\begin{array}{ccc}\text { Paper } & \mathrm{E} / & \text { Examples of the description of the data analysis process. } \\ \text { (Comments in brackets) }\end{array}$

(a) Identification - a

Narrative Events were explored for indicators of identity change from teacher to process of self-knowing realised within narrative practices for teacher educators during times of transition. teacher educator through the course of the life story. Initial coding assigned labels to statements of identity, using either in vivo statements or summary words and phrases. Subsequently, codes were then clustered into categories that formulated the key indicators of identity, which are discussed in the findings section below. In order to address the second propositional statement, the narrative events were analysed using two a priori codes, for instances of critical self-reflection and particularly 'premise reflection' (Mezirow 1991), as evidence of transformative learning. Each instance of critical self-reflection or premise reflection was coded according to the nature of that reflective episode.

(b) Studying Head- NE - In the present study the headteachers are primarily the 'life story givers' and they teachers' Professional Lives: Getting the Life History provide data for the researcher. However, with the intention to move from life story to life history, the voices of headteachers, as given in their personal experience narratives, are being contextualized beyond the life of the individuals involved. Starting to interpret the interviews, it was helpful to explore Lieblich, et al (1998) distinctions between form and content and between making sense of whole stories and dividing them into segments or categories

- by discussing these with the headteachers in the second round

of interviews the aspirations of the project to help in the co-construction of life histories is being rewarded

- tensions of comparative work were felt due to the research team members' different orientations to analysis and representation. The results are presented as dimensions analyzed. - At this research stage the main challenges are in the areas of analysis and representation. A number of methodological issues are being addressed. In particular, we are working at an approach to analysis what is attuned to the form and meanings of the stories themselves and working backwards and forwards

between individual stories and the whole collection of stories.

[The description is explicit in comparison with most of the other papers in the sample, but it is still somewhat confusing. It was difficult to determine whether portrayal or content analysis had been used as the basis of the analysis. As everything is presented in text form, it is necessary to read through all the text and the presentation of the results as dimensions analysed in order to realise that the method is content analysis. It does become clear that the team was using a process of dialogical analysis; however, the procedure could be explained more clearly.]

(c) Teacher commit- E - Data collected in the full-life history interview were transcribed and preliminarily ment trends: Cases of Hong Kong teachers from 1997 to 2007. analysed to inform the thematic life history interviews. A computer package (N-Vivo) was used to assist the storage and retrieval of data. Informants' indications of commitment level in their career courses were represented by commitment indexes. Codes related to commitment objects, and factors contributing to commitment intensity in each one's life and career course were generated by a constant comparative method (Glaser and Strauss, 1967).

- By making constant comparisons across different cases or within the same case at different phases of the study, properties and dimensions were identified and represented by the emerging codes.

[The analysis process is explained and presented in the form of tables.] 


\section{Paper E/ Examples of the description of the data analysis process. $\mathrm{NE}^{\text {a }} \quad$ (Comments in brackets)}

(d) Journey Through NE Transformation: A Case Study of Two Literacy Learners.
- The research approach is based on a range of strategies that include participatory action research (PAR) and a range of theoretical positions such as the feminist standpoint theory. It also draws on life history, literacy studies, and ethnographic approaches to exploring social practices

[The methodology is explained except for the method of analysis. It is obvious from the presentation of results that portrayal has been used; however, it is not mentioned or described in the paper.]

(e) The standards agenda: reflections of a special educational needs co-ordinator.

(f) Childcare choices and voices: Using interpreted narratives and thematic meaning-making to analyse mothers' life histories presenting factual accounts of lives that have been lived. experiences of a primary special educational needs co-ordinator (Bev) participating in a series of interviews. mentioned. A reading of the text shows that portrayal was used, but the process is not explained. The complete account as written by the informant is presented in the text.]

E Stage 1 - Transcription; the first stage producing the 'Original Transcript'. them - the result being the 'Refashioned Transcript'.

Stage 3-Editing the refashioned transcripts into a 3000-word interpreted narrative, which became the 'Interpreted Narrative'. A word limit of 3000 was my means of
NE - This study uses a life history approach. A life history approach was appropriate because it provided a way of examining the impact of the changing discourses of inclusion over time of children with special educational needs and their teachers. Goodson and Sikes $(2001, p$. 17) suggest that life histories 'confront issues surrounding the changing contexts of time and space. They provide detailed interpretations of lives rather than

- The paper provides an account from a single informant. It examines the professional

throughout the duration of her teaching career. /.../Bev focused heavily on tensions during the data collection process. Bev documented her own account rather than

[It is stated in the paper that LHM was used, but the method of analysis is not

Stage 2 - Removal of hesitative utterances -umms and ahh's and my responses - so as to bring coherence to the transcripts and as Riessman (1993) suggests, to 'refashion' restricting the refashioned script in a way that required I identified the 'core' of each transcript, and introduced a discipline which restricted the possibility of limitless rewriting. It was also a manageable amount of text to ask participants to reread as it was my interpretation of their original story.

Stage 4-Applying a Thematic Analysis approach to bring further interpretive meaning to the original transcripts (produced in stage 1).

[The stages were presented schematically. In addition to the overview, all the stages are described in detail, including the steps involved in Stage 4 - Thematic Analysis. Every stage was illustrated with an example, e.g., a section of the text from the original transcript and interpreted narrative.]

(g) 'Fire Burn and NE [A chapter titled "Narrative, memory and experience" provides an explanation Cauldron Bubble': What are the Conjunctural Effects on English Teacher Professional Memories, Identities and Narratives?

(h) European Early NE Childhood Education Research Journal of how the memories of professional teachers can be used in research through narratives placed in their historical context. However, the analysis process is not described. The results are presented in the form of a discussion that follows the themes that emerged in the narratives. A holistic perspective is applied to the teachers' stories; therefore, we are able to deduce that a type of categorical content analysis combined with holistic content analysis has been used, although the process is not explicit.]

[The researchers do not explain the analysis process, but the presentation of results according to themes indicates that a type of content analysis has been used. The process by which these conclusions were reached may not be clear to readers who are unfamiliar with content analysis.] 


\section{Paper E/ Examples of the description of the data analysis process. NE a (Comments in brackets)}

(i) We Love Our NE The first step that we took was to discern scripts that showed particular aspects of Public Schools: Art Teachers' Life Histories in a Time of Loss, Accountability, and New Commonalities individual experience located in time and space.

The second step was to examine the potentiality of the testimonies to collaborate and intertextualise. This meant that what one testimony said may have either resonated or been extended in the testimony of the others, allowing the reader to envision the personal through shared cultural narratives of subjectivity, power, desire, and hope (Goodson, 2008).

The third step was to produce the narrative, which initially took the shape of a 'video documentary'.

[We do not consider this explanation to be explicit as, first of all, it is too general. Second, the video documentary, an important component of the results, could not be included in the paper, although instructions for accessing the video have been provided in the endnotes. While it can be deduced from the video format that portrayal has been used, this is not clearly explained.]

${ }^{a}$ Explicit/Not Explicit. Our comments are provided in brackets.

Gauta 20190508 / Received 08052019

Priimta 20190716 / Accepted 16072019 